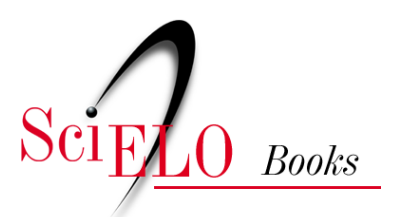

\title{
Reflexões \\ A leitura está de luto
}

\author{
Nelson De Luca Pretto
}

PRETTO, N.D.L. A leitura está de luto. In: Educações, culturas e hackers: escritos e reflexões [online]. Salvador: EDUFBA, 2017, pp. 128-130. ISBN: 978-85-232-2019-8.

https://doi.org/10.7476/9788523220198.0025.

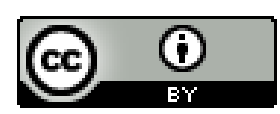

All the contents of this work, except where otherwise noted, is licensed under a Creative Commons Attribution $\underline{4.0 \text { International license. }}$

Todo o conteúdo deste trabalho, exceto quando houver ressalva, é publicado sob a licença $\underline{\text { Creative Commons }}$ Atribição 4.0.

Todo el contenido de esta obra, excepto donde se indique lo contrario, está bajo licencia de la licencia $\underline{\text { Creative }}$ Commons Reconocimento 4.0. 
dizendo que foi o melhor evento que assistiu. Nos seus dez anos de vida nunca o vi tão maravilhado com alguma coisa. Parabéns a quem tanto já trabalhou pelo incentivo à leitura."

Dez anos e maravilhado com a leitura, quer coisa melhor para um educador?

Saio de Passo Fundo literalmente renovado e com a alma lavada, por uma inundação de cultura e generosidade.

Vida longa para a Jornada Nacional de Literatura de Passo Fundo e que ela estimule outras universidades e prefeituras desse enorme Brasil a seguir o seu exemplo.

Publicado na revista digital Terra Magazine, São Paulo, em 2 de fevereiro de 2013.

\section{A leitura está de luto}

A notícia correu veloz e mobiliza muita gente: a Jornada Nacional de Literatura de Passo Fundo foi cancelada.

A reação de escritores, intelectuais, professores, jovens e crianças, de lá e de cá, foi de indignação. É inacreditável que um evento da magnitude da Jornada seja cancelado, mesmo em tempo de crise. Nesses momentos, lamentavelmente, sempre quem mais sofre é a cultura, considerada que é um artigo supérfluo, um mero adorno.

Estive na última jornada, em uma atividade no palco principal, instalado em uma enorme tenda, com dezenas de milhares de pessoas (inscreveram-se naquela Jornada 35 mil pessoas!). Estava junto com o espanhol Cesar Coll, o português J. Antonio Furtado e o italiano Massimo Canevacci, sob a batuta de Ignacio de Loyola Brandão e Luciana Savaget, 
para debater a convergências das mídias. Foi uma maravilhosa conferência-festa! Tudo para celebrar a leitura.

Isso mesmo, a Jornada de Passo Fundo tem sido uma verdadeira celebração à leitura e, o melhor, sem preconceitos. Lá, obviamente, fala-se muito em livro, no seu tradicional suporte, impresso em papel. Mas muito mais do que isso, a programação sempre vai além, com debates e atividades considerando outros suportes, como tablets e celulares, e o que mais me impressionou, compreendendo plenamente as novas linguagens contemporâneas, os códigos, oferecendo à meninada presente encontros e oficinas para a experimentação de programação de computadores e robótica, construindo uma verdadeira Escola Hacker.

Essa é a jornada que está sendo destituída. Mas nós não vamos deixar. Circula na internet um manifesto esperando a sua assinatura e apoio. "Nós, escritores abaixo-assinados, chamamos a atenção dos demais parceiros [...] para o descaso sofrido pelas Jornadas Literárias de Passo Fundo, no Rio Grande do Sul, na pessoa de sua criadora e organizadora, a professora Tânia Rösing, que, após trinta de anos de luta pelo fortalecimento do livro e da leitura, por falta total de apoio e de sensibilidade do Ministério da Educação, do Ministério da Cultura, das secretarias estadual e municipal de cultura de sua região e de patrocinadores, teve que cancelar a edição deste ano".

Continuamos no manifesto a indicar o significado desse evento-processo: "em mais de três décadas, as Jornadas firmaram-se como um dos mais importantes eventos do país de incentivo à leitura e à escrita, reunindo nomes consagrados e aproximando autores, artistas e intelectuais aos leitores para, juntos, debaterem as mais diversas temáticas relacionadas à literatura. O número de participantes em uma mesma edição chegou aos mais de 35 mil, em 2011 e 2013, e, no somatório das três décadas, superou 180 mil".

A preparação das crianças e jovens da região acontece muito antes do evento propriamente dito, dentro das escolas públicas, onde professoras animadas leem com seus alunos os autores que estarão presentes, em carne e osso, durante a Jornada. Vale lembrar que a cidade de Passo Fundo tem o maior índice de leitura do país (6,3 livros ao ano por habi- 
tante contra 1,3 do Brasil), fruto, seguramente, do trabalho promovido pelas Jornadas Literárias. O evento é, portanto, o ápice de um processo que envolve encontros mensais, com autores, professores e estudantes. Os alunos leem e discutem os livros e vão ao evento, incentivados a dialogar com seus escritores preferidos.

É urgente uma rápida e dura reposta a esse crime contra a leitura e a literatura no país. Assine o manifesto. ${ }^{23}$ Contribua com a Jornada, porque, como diz o escritor gaúcho Fabrício Carpinejar, "é mais fácil quando as coisas são impossíveis”. Complementa Carpinejar: "o reitor José Carlos Carles de Souza será conhecido como o gestor que terminou com o sonho da Jornada Nacional de Literatura de Passo Fundo. Não é um bom epitáfio."

Publicado em versão reduzida no jornal A Tarde, Salvador, em 13 de junho de 2015.

\section{Cinema, patrimônio e educação: sejamos primitivos!}

Acontece até a próxima segunda, dia 2 de junho, a 9a Mostra de Cinema de Ouro Preto (CINEOP) ${ }^{24}$ na bela cidade mineira, histórica e cercada de exuberantes montanhas. (Os mais velhos devem lembrar o tempo e que colocávamos uns plásticos no vidro dos carros. Pois eu gostava muito de um que circulava aqui por Minas que dizia: olhe bem as montanhas).

O CINEOP desse ano (2015) é dedicado a três grandes nomes do cinema brasileiro: Cosme Alves Brito, Ricardo Miranda e Luiz Rosemberg Pinto. Os dois primeiros já falecidos e o último aqui presente e efu-

\footnotetext{
${ }^{23}$ O Manifesto ainda se encontra aqui: <bit.ly/apoiojornada>. Acesso em: 2 mar.2017

${ }^{24}$ Disponível em: <http://cineo.com.br>.
} 